\title{
In vitro Study of the Compatibility of Three Fungicides with Biocontrol Agents Trichoderma asperellum and Pseudomonas protegens
}

\author{
Benedicto Martínez Coca $^{1}$ and Edwin Ronnie Gakegne ${ }^{2 *}$
}

${ }^{1}$ Centro Nacional de Sanidad Agropecuaria (CENSA), Apartado 10, San José de las Lajas, Mayabeque, CP 32700, Cuba

${ }^{2}$ Instituto de Investigação Agronômica (IIA), CP 405, Chianga, Huambo, Angola

*Corresponding author

\section{A B S T R A C T}

\section{Keywords}

Trichoderma asperellum,

Pseudomonas

protegens,

Fungicides,

Early blight,

Alternaria solani

Article Info

Accepted:

26 May 2020

Available Online:

10 June 2020
The objective of this work was to establish the compatibility under laboratory conditions, between three fungicides (Cuproflow $37.7 \%$ SC, Yaba M GD 66 and Mancozeb $80 \%$ WP) approved and regularly used to control early blight in Cuba and the biocontrol agents Trichoderma asperellum (strain Ta. 85) and Pseudomonas protegens (Pf-5). The effect of the concentrations of the chemical products, on the mycelial growth, sporulation of $T$. asperellum and the number of colonies of $P$. protegens was evaluated by the poisoned culture medium technique. The compatibility was classified according to the $T$ value. The results showed that the three fungicides affected the mycelial growth and the sporulation capacity of the strain of $T$. asperellum. The colonies of the strain of $P$. protegens were also affected by the recommended field dose for all tested fungicides. Cuproflow excelled for presenting the smallest affectation in all the performed tests, besides, it was also classified as compatible. The results bring out the probability of incorporating the biological control agents under study and Cuproflow $37.7 \%$ SCat low concentration in the integrated management of the Alternaria solani, causing early blight of potato. These results are novel and important for the application of microbial consortiums with synthetic fungicides. With the application of low dosages of fungicides, the appearance of resistant and aggressive pathogens can be limited. These will contribute to the preservation of environmental health.

\section{Introduction}

In general, early blight is considered one of the fungal diseases that cause the greatest economic losses on potato crop worldwide (Agrios, 2005; Mamgainet al., 2013; CABI, 2018). This disease attacks practically all the organs of the plant with a short-term harmfulness, capable of destroying the crop if not taking account of an efficient phytosanitary management (Hernández et al., 2016).

Various tactics are incorporated in the management of early blight: Cultural tactics, which provide the removal of stubble from the previous crop and weeds control, the use of healthy seed, the selection of tubers, the elimination of focal point of infections and the sanitation of affected leaves and stems, 
the non-adjacent with related crop areas such as tomato or the same crop with significant phenological differences (Castro and Contreras, 2011; Pérez and Forbes, 2011; MINAG, 2016).

Genetics, that suggests the use of resistant cultivars (Barna) or moderately resistant (Atlas, Ajiba, Romano and among others). The Chemicals, recommends the use of fungicides with a protective effect from the initial phenological stages of the crop, alternated with those of systemic action and curative, to avoid the appearance of fungiresistance (Wharton and Wood, 2013; MINAG, 2016).

The Biological ones, those show satisfactory results of the applications of biological products from the antagonistic microorganisms (fungi and bacteria) for the control of phytopathogen. Different strains of Trichoderma have shown a good antagonistic effect in vitro, against various Alternaria species (Murtaza et al., 2012; Khaliq et al., 2017; Ramakrishna et al., 2017). In the same way, Magesh et al., (2018), reported maximum growth reduction of $A$. solani in vitro, with Pseudomonas fluorescens strains. Gakegne and Martínez (2019) determined the efficacy of the biological product based on Pseudomonas protegens in the control of early blight of potato crop under field conditions.Regardless of these results, there are no yet promising antagonist strains for the control of early blight under field conditions.

However, the implementation of such an approach strongly relies on the compatibility between the biocontrol agents and the conventional synthetic fungicides. This study aimed to assess in vitro the compatibility between the $T a$. 85 strain of $T$. asperellum and the Pf-5 strain of $P$. protegens with three fungicides frequently used in the control of $A$. solani in potato cultivation.

\section{Materials and Methods}

\section{Origin of microbial cultures and inoculum production}

The work was carried out in the Laboratory of Plant Mycology and Plant Bacteriology of the National Center for Animal and Plant Health (CENSA) (Latitude 22.991867; Longitude 82.153892), Mayabeque Province, Cuba.

As microbial agents, $T$. asperellum strain Ta.85 belonging to the culture collection of the Laboratory of Plant Mycology and $P$. protegens strain Pf-5, from the culture collection of the Laboratory of Microbial Cultures of the Faculty of Biology of the University of Havana, were used. These strains were selected for their parasitic effect against $A$. solani in previous studies (Gakegne et al., 2017; Gakegne and Martínez 2018).

The inoculum of T. asperellum, was prepared by passing of discs of $5 \mathrm{~mm}$ diameter of the strain into Petri plates $(90 \mathrm{~mm} \varnothing)$ with Malta Agar medium (MA) (BIOCEN) and incubated for $72 \mathrm{~h}$ at $30 \pm 1^{\circ} \mathrm{C}$ in dark.

For the bacterial inoculum, the strain was prepared in Petri plates containing King B medium (BIOCEN) and incubated for $24 \mathrm{~h}$ at $28^{\circ} \mathrm{C}$. Subsequently, they were poured in test tubes containing $5 \mathrm{ml}$ of Nutrient Broth (NB) medium (BIOCEN) and incubated in agitation for $48 \mathrm{~h}$ in brand shaker (Thys 2) at $28^{\circ} \mathrm{C}$ and $150 \mathrm{rpm}$. The final cell suspension was prepared at a concentration of $10^{8} \mathrm{CFU}$.

Three fungicides: Cuproflow 37.7\% SC, Yaba M GD 66 and Mancozeb 80\% WP, used for the control of early blight in potato crop under the conditions of Cuba (MINAG, 2016), were tested for compatibility in vitro by poisoned food technique at three different concentrations 100, 80 and $60 \%$ of the recommended dosage (MINAG, 2016) as shown in table 1. The fungicide solutions 
were prepared in flasks with $25 \mathrm{ml}$ of distilled water previously sterilized for $15 \mathrm{~min}$ at $121^{\circ} \mathrm{C}$, and allowed to cool down to $40^{\circ} \mathrm{C}$ and each fungicide was added aseptically at the desired concentration and homogenized manually for $30 \mathrm{~s}$.

\section{Effect of fungicides on the mycelial growth of $T$. asperellum}

For this experiment, $25 \mathrm{ml}$ of the solution of fungicides were poured separately into the flask with $25 \mathrm{ml}$ medium Potato Dextrose Agar (PDA) (BIOCEN) pH 5.6 at $40^{\circ} \mathrm{C}$, and stirred manually for $30 \mathrm{~s}$, then poured into Petri plates $(90 \mathrm{~mm} \varnothing)$. After solidification, the plates were inoculated centrally with 5 $\mathrm{mm}$ disc of mycelium of $72 \mathrm{~h}$ hold $T$. asperellum taken from the periphery of actively growing colony. PDA Petri plates without the poisoned compounds were inoculated centrally with the antagonistic fungus served as controls. Three replicates (Petri plate) were used for each concentration of every tested fungicide. Petri plates were sealed with parafilm and incubated at $30 \pm$ $1^{\circ} \mathrm{C}$ in dark. The mycelial growth of $T$. asperellum was measured every $24 \mathrm{~h}$, upto 72 $\mathrm{h}$. To determine the effect of the fungicide on the mycelial growth of $T$. asperellum, the mycelial growth of the control plates was taken as reference. The percentage of radial growth inhibition was calculated according to the formula suggested by Abbott et al., (CibaGeigy, 1981).

\section{Effect of fungicides on the sporulation of T. asperellum}

The spores' suspension was obtaining by using the colony sweeping method. 7 days old colonies of antagonist, grown on PDA medium poisoned with the fungicides were used. To this end, $30 \mathrm{ml}$ of sterilized distilled water was added fractionally on the plate. The obtained suspension was placed in 160 x 20 $\mathrm{mm}$ test tubes, stirred for $30 \mathrm{~s}$ in a Vortex tube agitator. The counting of spores per quadrant was performed using the Neubauver chamber. With the collected data, the sporulation of the fungal growth area was calculated based on $\pi * \gamma 2$ and the percentage of inhibition of sporulation by the formula of Abbott et al., (CIBA-GEIGY, 1981).

The compatibility of each fungicide with the antagonistic fungus was calculated according to the $\mathrm{T}$ value proposed by Alves et al., (1998), and the two indicators evaluated above were used: percentage of inhibition of the mycelial growth and the effect on sporulative capacity through the formula:

$\mathrm{T}=[20 * \mathrm{CV}+80 *[\mathrm{ESP}] / 100$

where: $\mathrm{T}$ : Corrected value for the classification of the product

$\mathrm{CV}$ : Percentage of vegetative growth in relation to the control

ESP: Percentage of sporulation in relation to the control.

The $\mathrm{T}$ values were classified according to the scale established by Alves et al.,

$\begin{array}{ll}0 \text { a } 30 & \text { Very toxic } \\ 31 \text { a } 45 & \text { Toxic } \\ 46 \text { a } 60 & \text { Moderately toxic } \\ >60 & \text { Compatible }\end{array}$

Effect of fungicides on the Pf-5 strain of $P$. protegens

For this experiment, the culture media were prepared in a similar way to that described above. In Petri plates containing PDA, $10 \mu \mathrm{l}$ of the previously obtained bacterial suspension were inoculated, and spread uniformly, with a Drigalsky spatula. Control plates without the poisoning solution of fungicides were inoculated with the bacterial suspension using the same technique as the 
treatment plates. All plates were incubated at $30 \pm 1{ }^{\circ} \mathrm{C}$ in dark. Three replicates were used per variant. The number of colonies was evaluated every $24 \mathrm{~h}$, upto $72 \mathrm{~h}$. Inhibition percentages were calculated according to the formula suggested by Abbott et al., (CIBAGEIGY, 1981) and processed according to the proportional comparison test.

\section{Statistical analysis}

The data collected for all the experiments were tabulated in Microsoft Excel and processed by simple analysis of variance. Mean comparisons were conducted according to Tukey's multiple range comparison test for a significance level of $95 \%$. The statistical package Info Stat / Professional version 1.1 (Di Rienzo et al., 2016) was used. Percentage data were analyzed using the system for comparison of multiple proportions (COMPAPROP) (Castillo and Miranda, 2014). A completely randomized design was used for all experiments.

\section{Results and Discussion}

\section{Effect of fungicides on the mycelial growth of $T$. asperellum}

The three fungicides showed an inhibitory effect against the T. asperellum strain Ta. 85, at the tested concentrations with significant differences $(p \leq 0.05)$ (Table 2). Although no total fungicidal effect on this strain was observed in any of the variants, Mancozeb at the highest concentration inhibited strongly and progressively, up to $98.09 \%$ of the growth in the control.

Cuproflow $37.7 \%$ SC presented the lowest inhibitory effect of the mycelial growth of the antagonistic fungus at all concentrations, especially at the concentration of $60 \%$, that had significant differences with the remaining treatments, during the evaluation period. Mancozeb $80 \% \mathrm{PH}$, regardless of the concentration, presented the greatest inhibitory effect on the growth of $T$. asperellum in the three moments of the evaluation (Fig. 1).

The differential response of $T$. asperellum strain $T a .85$ against fungicides in the present study may be due to its tolerance to these fungicides and/or its metabolic capacity to degrade different substrates, among them. Durán et al., (2007) observed in vitro tests that copper oxychloride, metalaxyl and dimetomorf were compatible with different species of Trichoderma; while zineb, mancozeb and tiram showed slight toxicity and benomil behaved as toxic (Muiño et al., 2006). However, Trichoderma was reported to be capable of degrading organochlorines, chlorophenols, and insecticides such as dichloride diphenyl trichloroetane (DDT), endosulfan, pentachloronitrobenzene, aldrin, and dihedron, and herbicides such as trifluralin and glyphosate (Espósito and Dasilva, 1998). The effects of pesticides are also observed on the cultural characteristics of $T$. asperellum, with variations in the edges, coloration of the colonies and texture of the mycelium (Martínez et al., 2013).

The results evidenced the need to evaluate the compatibility of each new promising strain of antagonists with the agrochemicals used in the common application scenarios. From a practical point of view, this is of great importance in determining the timing of the application of the antagonist or of the agrochemical in crop management.

The results of the present investigation have a similar tendency to those obtained by Terrero et al., (2018), who observed that copper hydroxide had the lowest inhibitory effect, at low concentration against Trichoderma ovalisporum Samuels \& Schroers. The results of this work did not coincide with those of Shashikumar et al., (2019), nor with those of Nandini et al., (2018), who reported a $6.67 \%$ 
and $19.75 \%$ inhibitory effect of the mycelial growth of Trichoderma harzianum Rifaiand Trichoderma viride Pers ex S. F Gray, respectively, in the test with Mancozeb $75 \% \mathrm{WP}$, while in this present work the inhibition of the growth of $T$. asperellum ranged between 94.93 and $98.13 \%$ with Mancozeb $80 \%$ WP. From these results, it is inferred that, from a practical point of view, the applications of Mancozeb $80 \%$ WP have to be done 7 days before the application of biocontroller, since the residual time of the fungicide in the culture can be up to seven days.

\section{Effect of fungicides on the sporulation of $\boldsymbol{T}$. asperellum}

The three tested fungicides caused sporulation inhibition of the Ta. 85 strain (Fig. 2) in comparison to the control. The fungicide Cuproflow $37.7 \%$ SC presented the lowest inhibitory effect of the sporulation of the $T a$. 85 strain. Regardless of concentrations, Mancozeb 80\% WP completely inhibited the sporulation of the antagonistic fungus. These results are in agreement with those reported by Terrero et al., (2018), who informed that Trichodermais tolerant to a wide range of pesticides, and also Harman et al., (2004) expressed that this tolerance is an innate characteristic for this genus of fungus.

These results showed that the effect of fungicides is greater on sporulation, in relation to the effect on the mycelial growth of the Ta. 85 strain. These results are similar to those obtained by Guerrero and Arias (2012) who found that copper oxide did not inhibit the production of spores of Trichoderma koningiopsis Samuels. However, the inhibition of sporulation by fungicides influences the spread of the biological agent in the soil, which limits its controlling action.
According to the compatibility classification proposed by Alves et al., (1998), the fungicides Yaba and Mancozeb at all concentrations and Cuproflow at the concentration of $100 \%$ showed the high level of toxicity. Cuproflow at $60 \%$ showed the highest compatibility with $68.40 \%$ (Table 3 ). These results are similar to those obtained by Terrero et al., (2018) who observed that low concentration copper hydroxide showed compatibility with $T$. ovalisporum and Trichoderma stromaticum Samuels \& PardoSchulth. However, they do not match with the results of Nandini et al., (2018) who found compatibility between Mancozeb 75\% WP and $T$. viride. However; this fungicide was moderately toxic for A-34 strain of Trichoderma harzianum Rifai (Castellanos et al., 2015). This difference is due, either to the species of Trichoderma and / or to the strain.

There are investigations that suggest the compatibility or not of Trichoderma with cupric fungicides (Terrero et al., 2018). The direct effect on the growth of Trichoderma, may be associated with metal ions, such as copper, having an impact on the development of this type of fungi, particularly on the mycelial growth [Harman et al., (2004); Martínez et al., (2013)].

\section{Effect of fungicides on the Pf-5 strain of $\boldsymbol{P}$.} protegens

The tested fungicides inhibited the number of colonies of the $P$. protegens strain Pf-5, with significant differences $(\mathrm{p} \leq 0.05)$ compared to the control (Table 4), but none of them showed bactericidal effect. The lowest inhibitory effect was observed on Cuproflow $37.7 \%$ SC and the biggest on Mancozeb 80\% WP. Cuproflow, as in the previous experiment, is the product that showed the highest compatibility with $P$. protegens compared to the remaining fungicides (Fig. $3)$. 
The results with Mancozeb coincide with those obtained by Mohiddin and Khan (2013) who did not observe compatibility between Pseudomonas fluorescens Migula and this fungicide. Although, Nandini et al., (2018) found compatibility between Mancozeb 75\% WP and $P$. fluorescens; however, they correspond to the results with the $\mathrm{Cu}$ base fungicide, finding compatibility between them.

In general, fungicide treatments, although they show significant differences among them, they showed that these antagonists have very few tolerances to the tested fungicides.
These results prove that BCAs could be used with these products at low concentrations, which would reduce environmental contamination. Despite the fact that no fungicidal effect or bactericidal effect was found in any of the treatments, it was statistically observed that $P$. protegens proved to be more tolerant than $T$. asperellum to the tested fungicides, which confirms the said by Aislabie and Jones (1995) who demonstrated that Pseudomonas is more tolerant to fungicides than fungi, and that this could be because some bacteria can use pesticides as a source of nutrients and, therefore, can tolerate high concentrations of chemicals.

Table.1 Fungicides used in the test

\begin{tabular}{|l|l|l|}
\hline Fungicides & Active ingredient & Field dosage \\
\hline Cuproflow 37.7 \% SC & Copper Oxychloride & $2.5 \mathrm{~L} \mathrm{(PC)} \cdot \mathrm{ha}^{-1}$ \\
\hline Yaba M GD 66 & Valifenalate+mancozeb & $2.5 \mathrm{~kg}(\mathrm{PC}) \cdot \mathrm{ha}^{-1}$ \\
\hline Mancozeb 80 \% WP & Manozeb & $2.0 \mathrm{~kg}$ (i.a). $\mathrm{ha}^{-1}$ \\
\hline
\end{tabular}

Table.2 Inhibitory effect of different concentrations of fungicides on the mycelial growth of T. asperellum

\begin{tabular}{|l|l|l|l|}
\hline \multirow{2}{*}{$\begin{array}{c}\text { Treatments } \\
\text { (Ta.85) }\end{array}$} & \multicolumn{3}{|l|}{ Percentage of inhibition of the mycelial growth } \\
\cline { 2 - 4 } & $24 \mathrm{~h}$ & $48 \mathrm{~h}$ & $72 \mathrm{~h}$ \\
\hline Cuproflow 100\% & $91.53 \mathrm{bc}$ & $84.88 \mathrm{~cd}$ & $75.82 \mathrm{c}$ \\
\hline Cuproflow 80\% & $87.36 \mathrm{~b}$ & $71.69 \mathrm{~b}$ & $68.19 \mathrm{~b}$ \\
\hline Cuproflow 60\% & $57.36 \mathrm{a}$ & $53.66 \mathrm{a}$ & $41.91 \mathrm{a}$ \\
\hline Yaba 100\% & $93.61 \mathrm{bc}$ & $91.45 \mathrm{def}$ & $85.27 \mathrm{~d}$ \\
\hline Yaba 80\% & $89.31 \mathrm{bc}$ & $88.72 \mathrm{cde}$ & $81.47 \mathrm{~cd}$ \\
\hline Yaba 60\% & $85.14 \mathrm{~b}$ & $81.09 \mathrm{c}$ & $80.14 \mathrm{~cd}$ \\
\hline Mancozeb 100\% & $96.81 \mathrm{c}$ & $98.13 \mathrm{f}$ & $98.09 \mathrm{e}$ \\
\hline Mancozeb 80\% & $96.81 \mathrm{c}$ & $96.69 \mathrm{ef}$ & $95.53 \mathrm{e}$ \\
\hline Mancozeb 60\% & $96.81 \mathrm{c}$ & $95.24 \mathrm{ef}$ & $94.93 \mathrm{e}$ \\
\hline ESx & 0.84 & 1.87 & 2.79 \\
\hline
\end{tabular}

Means with different letters, in the same column differ significantly ( $\leq \leq 0.05$, according to Tukey's multiple range test). 
Table.3 Classification of the toxicity of fungicides on T. asperellum

\begin{tabular}{|l|c|c|}
\hline \multicolumn{1}{|c|}{$\begin{array}{c}\text { Fungicides } \text { / } \\
\text { Concentration }\end{array}$} & \multicolumn{2}{|c|}{ Compatibility (Alves et al., } \\
\hline Cuproflow 100\% & 23.13 & Classification \\
\hline Cuproflow 80\% & 46.65 & Very toxic \\
\hline Cuproflow 60\% & 68.40 & Moderately toxic \\
\hline Yaba 100\% & 13.44 & Compatible \\
\hline Yaba 80\% & 18.40 & Very toxic \\
\hline Yaba 60\% & 22.28 & Very toxic \\
\hline Mancozeb 100\% & 0.38 & Very toxic \\
\hline Mancozeb 80\% & 0.89 & Very toxic \\
\hline Mancozeb 60\% & 1.01 & Very toxic \\
\hline
\end{tabular}

Table.4 Inhibitory effect of different concentrations of fungicides on the colonies number of $P$. protegens

\begin{tabular}{|c|c|c|c|}
\hline \multirow[t]{2}{*}{$\begin{array}{l}\text { Treatments } \\
\qquad(\text { Pf-5) }\end{array}$} & \multicolumn{3}{|c|}{$\begin{array}{c}\text { *Percentage of inhibition of number of the } \\
\text { colonies } P \text {. protegens }\end{array}$} \\
\hline & $24 \mathrm{~h}$ & $48 \mathrm{~h}$ & $72 \mathrm{~h}$ \\
\hline Cuproflow $100 \%$ & $74.23 \mathrm{c}$ & $70.29 \mathrm{c}$ & $59.04 \mathrm{c}$ \\
\hline Cuproflow $80 \%$ & $61.50 \mathrm{~b}$ & $59.50 \mathrm{~b}$ & $48.42 \mathrm{~b}$ \\
\hline Cuproflow $60 \%$ & $34.57 \mathrm{a}$ & $42.75 \mathrm{a}$ & $30.22 \mathrm{a}$ \\
\hline Yaba $100 \%$ & $94.98 \mathrm{ef}$ & 90.14 ef & $81.00 \mathrm{f}$ \\
\hline Yaba $80 \%$ & $90.40 \mathrm{e}$ & $87.35 \mathrm{e}$ & $76.28 \mathrm{e}$ \\
\hline Yaba $60 \%$ & $82.66 \mathrm{~d}$ & $80.74 \mathrm{~d}$ & $67.79 \mathrm{~d}$ \\
\hline Mancozeb $100 \%$ & $98.48 \mathrm{f}$ & $96.45 \mathrm{f}$ & $94.20 \mathrm{~g}$ \\
\hline Mancozeb $80 \%$ & 95.74 ef & $94.67 \mathrm{f}$ & $91.27 \mathrm{~g}$ \\
\hline Mancozeb $60 \%$ & 95.37 ef & 87.89 e & $85.74 \mathrm{f}$ \\
\hline ESx & 4.96 & 7.01 & 7.29 \\
\hline
\end{tabular}

Means with different letters, in the same column differ significantly ( $\leq \leq 0.05$, according to Tukey's multiple range test). 
Figure.1 Mycelial growth (mm) of T. asperellum in culture medium with fungicides at different Concentrations at 7 days. A: Cuproflow 37,7 \% SC: a) 60\%, b) 80\%, c) 100\%. B: Yaba M GD 66: a) 60\%, b) $80 \%$, c) 100\%. C: Mancozeb $80 \%$ WP: a) 60\%, b) $80 \%$, c) $100 \%$. D: Control without fungicides

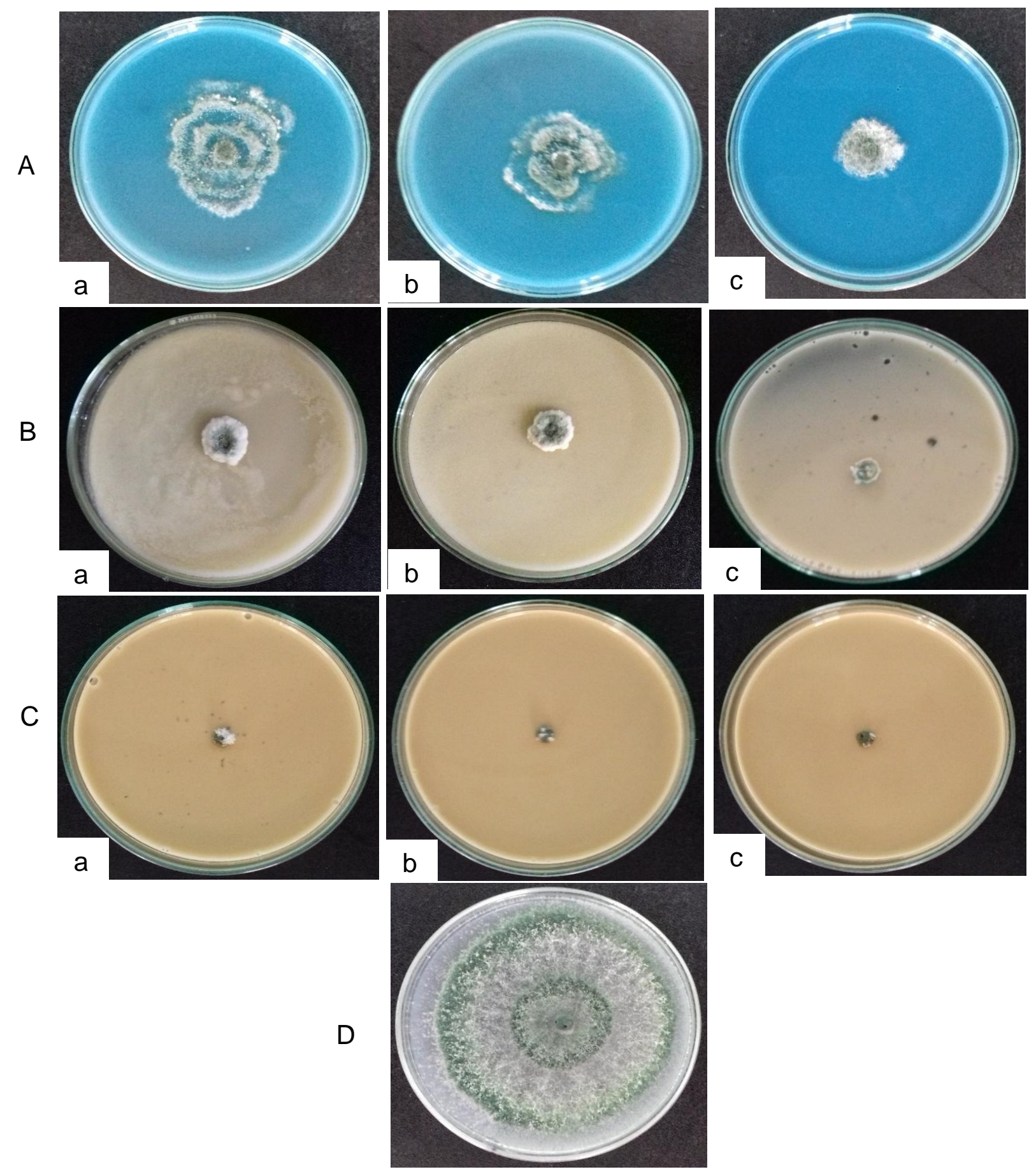


Figure.2 Inhibitory effect of fungicides at different concentrations on the sporulation of T. asperellum at 7 days

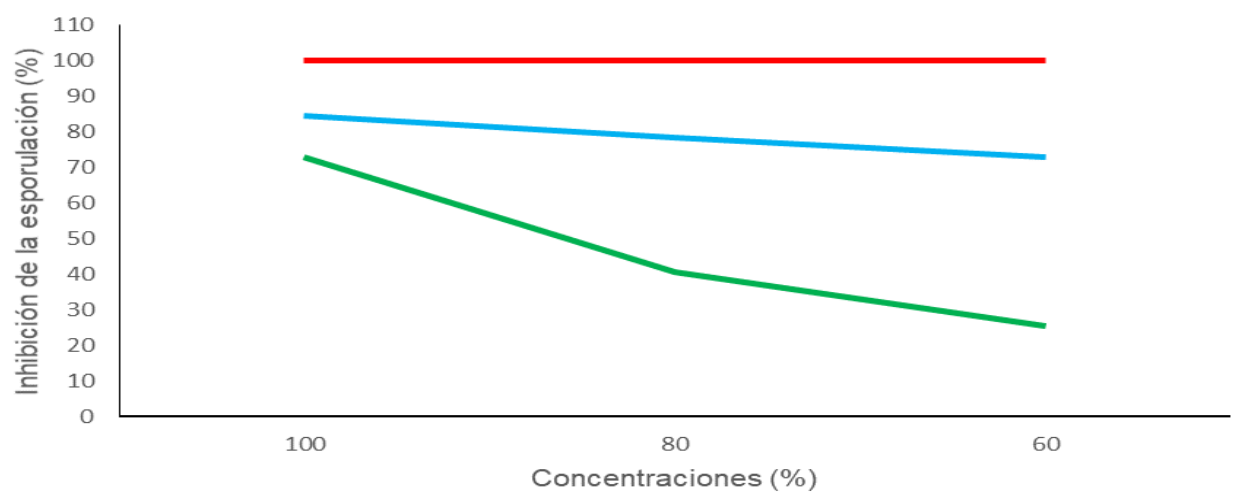

Mancozeb Yaba Cuproflow

Figure.3 Effect of different concentrations of fungicides on number of the colonies of P. protegens A: Cuproflow 37,7 \% SC: a) 60\%, b) 80\%, c) 100\%. B: Yaba M GD 66: a) 60\%, b) 80\%, c) 100\%. C: Mancozeb $80 \%$ WP a) $60 \%$, b) $80 \%$, c) $100 \%$. D: Control.

$\Delta$
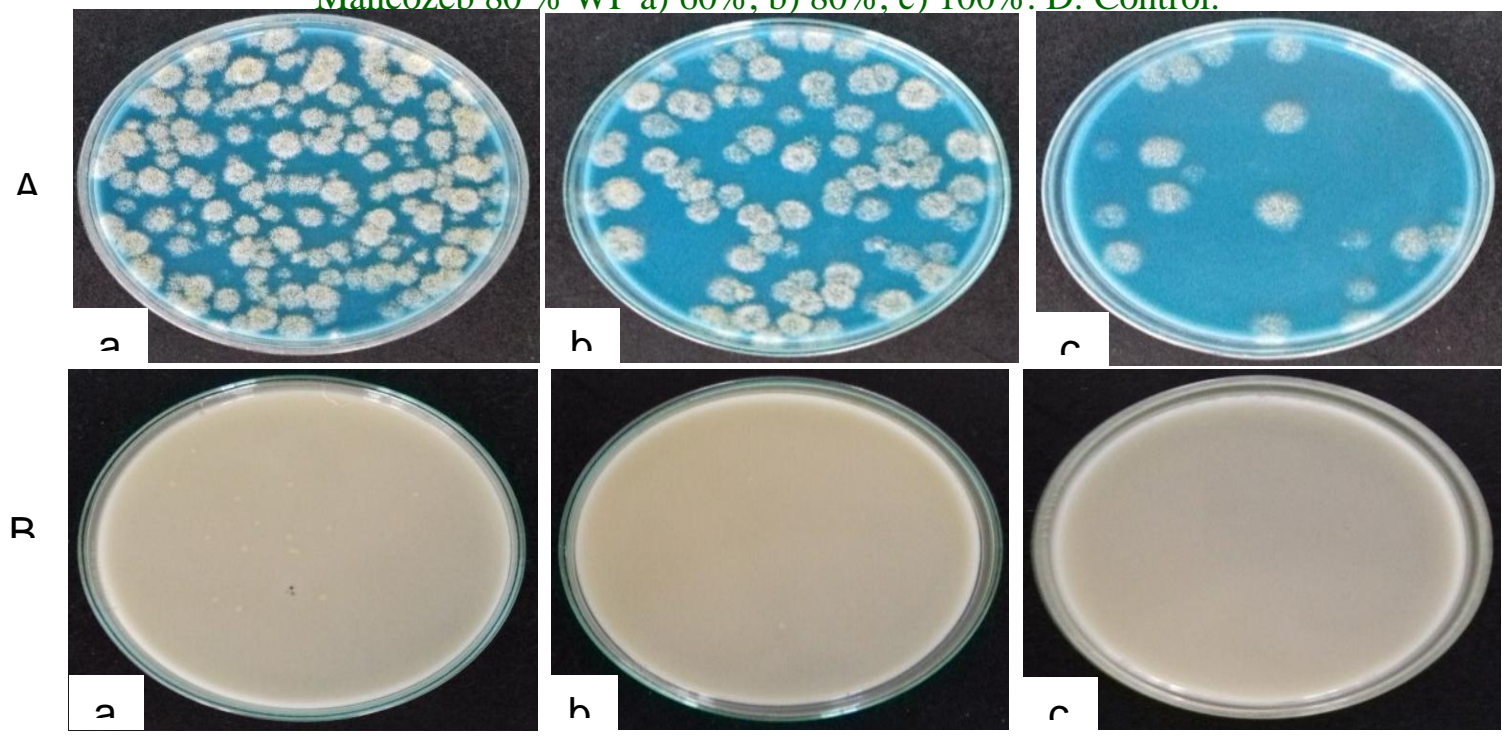

$n$
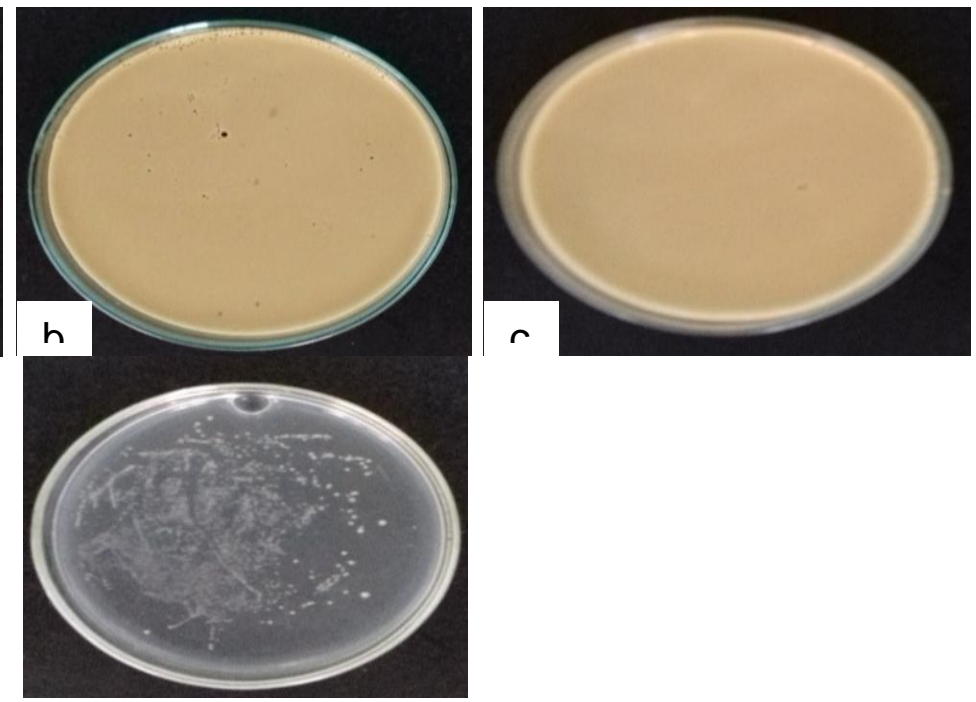
To develop an effective disease management programme, the compatibility of potential bioagents with fungicides is essential. Combining antagonists with fungicides may eliminate the chance of resistance development and reduces the fungicide application.

The results obtained in this work leave open the possibility of integrating the BCAs under study and the fungicide Cuproflow $37.7 \%$ SC, at low concentration in the integrated management of $A$. solani in the potato crop, which confirms the said by Erayya et al., (2018) who indicated that the integration of bio-agents with lower concentration or sublethal doses of fungicides is becoming an acceptable technological-approach in sustainable agriculture. This must be verified in the field conditions with the aim to enhance crop health and productivity as stated by Kumar et al., (2019) the integration of compatible bioagent with fungicides, may enhance the effectiveness of disease control and provide better management of diseases. Hence, the combination of biological control agents with fungicides would provide similar disease suppression as achieved with higher fungicide use.

In conclusions, organic measures to combat plants disease are the need of the hour and highest priority has been given for this. However, bio-agents have not yet attained efficiencies matching those of currently available fungicides. Integration of fungicides with bio-control agents will be a better option for improving the efficiency of bio-control agents. Combined application of chemical and bio- agents will help in outspreading the period of active disease control as well as reducing the cost of crop protection. Cuproflow fungicide $37.7 \%$ SC at low concentration showed high compatibility with the Ta. 85 strain of $T$. asperellum and Pf-5 of $P$. protegens under in vitro conditions.

\section{References}

Agrios, G.N. 2005. Plant Pathology. 5th ed. Elsevier Academic Press, San Diego, USA. Pp. 922.

Aislabie, J., and Jones, G. 1995. A review of bacterial degradation of pesticides. Aust. J. Soil Res. 33: 925-942.

Alves, S. B., and Moino, J. E. M. 1998. Almeida: Produtos fitossanitários entomopatógenos In: Alves, S. B.(ed.).Controle microbiano de insetos, FEALQ, Piracicaba, Brasil.; pp. 217-238.

Castellanos, G. L., Lorenzo M. E., Muiño, B. L., Hernández, P. R., Guillen, S. D. 2015. In vitro effect of commercial pesticides on Trichoderma harzianum strain A- 34. Rev. FCA UNCUYO. 47(2): 185-196.

Castillo, Y., and Miranda, I. 2014. COMPAPROP: Sistema para comparación de proporciones múltiples. Rev. Protección Veg.; 29(3): 231-234.

Castro, I., and Contreras A. 2011. Manejo de plagas y enfermedades en el cultivo de la papa. Imprenta Austral, ValdiviaChile. 1-72.

Centre for Agriculture and Biosciences International (CABI). 2018. Alternaria solani (early blight of potato and tomato). Invasive Species Compendium. En: https://www.cabi.org/isc/datasheet/45 28\#totaxonomicTree

CIBA-GEIGY. 1981. Manual para ensayos de campo en protección vegetal. Segunda edición revisada y ampliada. Editado y publicado por Werner Püntener, División Agricultura, CIBA-GEIGY S.A. Basilea, Suiza. Pp. 33-35.

Di Rienzo, J., Balzarini, M., Casanoves, F., González, L., Tablada, M., Walter, R. 2016. InfoStat versión 1.1. Grupo InfoStat, FCA, Universidad Nacional 
de Córdoba, Argentina.

Durán, E., De Romero, Y., Romero, M., Ramallo, J. In vitro sensitivity of Trichoderma strains isolated from soybean seeds against the MAXIM® XL fungicide. Mycological Bulletin. 2007; 22: 51-54

Erayya, S. N., Balodi, R., Tewari, A.K., Kumar, J. 2018. Compatibility of Trichoderma with Copper-Chitosan Graded Combinations, Int. J. Pure App. Biosci. SPI: 6(3): 631-634.

Espósito, E., andDasilva, M. 1998. Systematics and environmental application of the genus Trichoderma. Microbiology. 24:89-98.

Gakegne, E. R., and Martínez, C. B. 2018. Antibiosis y efecto de $\mathrm{pH}$ temperaturasobre el antagonismo de cepas de Trichoderma asperellum frente a Alternaria solani Rev. Protección Veg. 33(2):1-9.

Gakegne, E. R., Plasencia, O., HernándezRodríguez, A., de La Fe, Y., Martínez C. B. 2017. Actividad antagónica de Pseudomonas spp. fluorescentes ante Alternaria solani Sorauer, patógeno de la papa (Solanum tuberosum L.). Rev. Protección Veg.; 32(3): 1-11.

Guerrero, R., and Arias, D. 2012. Evaluación del efecto de fungicidas sobre el desarrollo de dos especies de Trichoderma (Fungi: Ascomycota: Hypocreaceae) utilizadas en el biocontrol de hongos patógenos de cacao.Agroecología.; 1(1): 1-8.

Harman, G., Viterbo, A., Chet, I., Lorito, M. 2004. Trichoderma species-opportunistic, avirulent plant symbionts. Nature Reviews. Microbiology. 2(1): 43-56.

Hernández, O., Castillo, D., Herrera, R., Fuentes, E., Drouaillet, E., Santillán, A. 2016. Actividad antagónica de Trichoderma spp. sobre Rhizoctonia solaniin vitro. Investigación y Ciencia.
24(67): 5-11.

Joseph, A., Best-Igbinosa, O., Tope-Alori, E., Ademiluyi, O., Aluko, A. 2017. Effectiveness of Pseudomonas species in the management of tomato early blight pathogen Alternaria solani. African journal of microbiology research. 11(23): 972-976.

Khaliq, A., Khan, H., Khan, N., Zada, L., Ali, M., Zahoor. M., et al., 2017. In vitro efficacy of Trichoderma harzianum Rifai against various isolates of Alternaria sp. Journal of Entomology and Zoology Studies. 5(1): 442-445.

Kumar, A., Bansal, R. D., Chelak, K. Y. 2019. Compatibility of Trichoderma viride with Fungicides for Plant Disease Management. Int. J. Pure App. Biosci. 7 (3): 44-51.

Magesh, M., Sudha, R., Ahila-devil, P. 2018. Impact of rhizosphere Pseudomonas fluorescence against Alternaria solani in tomato. J.Bio.Innov. 7(2): 242-251.

Mamgain, A., Roychowdhury, R., Tah, J. 2013. Alternaria pathogenicity and its strategic controls. Res. J. Biol. 1: 1-9.

Martínez, C. B., Infante, D., Reyes, Y. 2013. Trichoderma spp. y su función en el control de plagas en los cultivos. Rev. Protección Veg. 28(1): 1-11.

Ministerio de la Agricultura (MINAG). 2016. Instructivo Técnico para la producción de papa en Cuba. Dirección de Agricultura. Editorial Ministerio de Agricultura. La Habana, Cuba. 62.

Mohiddin, A., and Khan, R. 2013. Tolerance of fungal and bacterial biocontrol agents to six pesticides commonly used in the control of soil borne plant pathogens. Glob. J. Pest Dis. Crop Prot. 1(1): 1-4.

Muiño, B., Sáenz, M., Stefanova, M., Pomas, A., Díaz, I. 2006. Compatibilidad de Trichoderma spp. con plaguicidas $\mathrm{y}$ fertilizantes en el cultivo del tabaco (N. tabacum L.). Fitosanidad. 
10(2): 153 .

Murtaza, A., Shafique, S., Anjum, T., Shafique, S. 2012. In vitro control of Alternaria citri using antifungal potentials of Trichoderma species. African Journal of Biotechnology. 11(42): 9985-9992.

Nandini, M., Ruth, C., Gopal, K. 2018. Compatibility of biocontrol agents with fungicides used in turmeric cultivation under in vitro conditions. Res. J. Chem. Env. Sci.; 6(4): 19-25.

Pérez, W., and Forbes, G. 2011. Guía de identificación de plagas que afectan a la papa en la zona andina. Centro Internacional de la Papa (CIP). 1-48.

Ramakrishna, A., Desai, S., Uma, G., Uma, M. T. 2017. Efficacy of different isolates of Trichodermaagainst early blight of tomato. Journal of Pharmacognosy and Phytochemistry.
6(5): 1060-1062.

Shashikumar, M., Sumangala, K., Navyashree, E. 2019. Compatibility of Trichoderma viride and Trichoderm aharzianum with Fungicides against Soil Borne Diseases of Tomato and Cabbage. Int. J. Curr. Microbiol. App. Sci. 8(4): 1920-1928.

Terrero, P., Peñaherrera, S., Solís, Z., Vera, D., Navarrete, J., Herrera, M. 2018. Compatibilidad in vitro de Trichoderma spp. con fungicidas de uso común en cacao (Theobroma cacao L.). Investig. Agrar.; 20(2):146151.

Wharton, P., and Wood, E. 2013. Early blight biology and control in potatoes. University of Idaho. College of Agriculture and Life Sciences. 1-5.

\section{How to cite this article:}

Benedicto Martínez Coca and Edwin Ronnie Gakegne. 2020. In vitro Study of the Compatibility of Three Fungicides with Biocontrol Agents Trichoderma asperellum and Pseudomonas protegens. Int.J.Curr.Microbiol.App.Sci. 9(06): 3355-3366.

doi: https://doi.org/10.20546/ijcmas.2020.906.398 